\title{
Nitrogen recovery and agronomic efficiency of forages with nitrogen fertilization under flooded condition
}

\author{
Gilbert C. Sigua ${ }^{{ }^{*}}$, Mimi M. Williams ${ }^{2}$, Chad C. Chase Jr. ${ }^{3}$, Janet Grabowski ${ }^{2}$, \\ Manoch Kongchum ${ }^{4}$ \\ ${ }^{1}$ United States Department of Agriculture, Agricultural Research Service, Florence, USA \\ *Corresponding Author: gilbert.sigua@ars.usda.gov \\ ${ }^{2}$ United States Department of Agriculture, Natural Resources Conservation Service, Brooksville, USA \\ ${ }^{3}$ United States Department of Agriculture, Agricultural Research Service, Clay Center, USA \\ ${ }^{4}$ School of Plant, Environmental, and Soil Sciences, Louisiana State University Agricultural Center, Baton Rouge, USA
}

Received 7 January 2013; revised 10 February 2013; accepted 25 February 2013

\section{ABSTRACT}

The cow-calf (Bos taurus) industry in subtropical United States and other parts of the world that depends almost totally on grazed pastures is facing several production constraints like changing climatic conditions and increasing cost of fertilizers, especially nitrogen (N). Particularly little is known about the response of forage species to the combined effect of waterlogging and the addition of N. A two-year greenhouse study was conducted in 2008 and 2009 to determine i) the effect of flooding duration on $\mathrm{N}$ recovery and agronomic efficiency of bahiagrass (Paspalum notatum Fluegge) compared with two flooding tolerant forages, limpograss (Hemarthria altissima Poir), and maidencane (Panicum hematomon Schult) and ii) if $\mathrm{N}$ fertilization could mitigate the negative effect of flooding. Nitrogen recovery and agronomic efficiency varied significantly $(P \leq 0.001)$ among forage species. Averaged across levels of $N, N$ recovery of bahiagrass and limpograss was reduced by about $41 \%$ and $56 \%$, respectively after $84 \mathrm{~d}$ of continued flooding while $\mathrm{N}$ recovery of maidencane was slightly increase by about $5 \%$ between 0 and $84 \mathrm{~d}$ of flooding. Agronomic efficiencies of bahiagrass $(41 \%$ to $26 \%)$ and limpograss $(44 \%$ to $31 \%)$ were reduced by flooding while agronomic efficiency of maidencane was increased from $24 \%$ (no flooding) to $46 \%$ at $84 \mathrm{~d}$ of continued flooding. However, $\mathrm{N}$ recovery and agronomic efficiency of three forage species was positively affected by $\mathbf{N}$ fertilization. The overall $\mathbf{N}$ recovery of bahiagrass, limpograss, and maidencane ranged from $44 \%$ to $59 \%$. Ni- trogen fertilization could improve $\mathbf{N}$ recovery and agronomic efficiency of forage species under waterlogged condition.

Keywords: Forages; Nitrogen Recovery; Agronomic Efficiency; Flooding; Nitrogen

\section{INTRODUCTION}

Low soil fertility is one of the most important factors constraining forage productivity in subtropical United States especially in Gulf Coast states, as well as other parts of the world where cow-calf operation depends almost totally on grazed pastures. The use of inorganic $\mathrm{N}$ fertilizer will continue to be indispensable for meeting global food, feed, and fiber needs [1]. Particularly little is known about the response of forage species to the combined effect of waterlogging and the addition of nutrients (e.g., $\mathrm{N}$ and $\mathrm{P}$ ). Fertilizer application may reverse the detrimental processes associated with flooding, however relatively few studies and reports are available on the ability of $\mathrm{N}$ fertilizer to counteract the deleterious effects of waterlogging on terrestrial plants [2,3]. The use of $\mathrm{N}$ fertilizer prior to flooding may alleviate $\mathrm{N}$ deficiency because waterlogging causes a significant decrease in $\mathrm{N}$ content and rate of $\mathrm{N}$ accumulation in plants due to reduced root activity [4].

Flooding can have catastrophic impacts on the productivity of grassland pastures, as most forage species are intolerant to excess water. In grasslands, waterlogging is frequently associated with other stresses, such as grazing, which may require specific and very different adaptive strategies and management $[5,6]$. These adaptive strategies are not well understood and may still warrant extended investigations. Driven by a growing concern that 
crop nutrients are becoming excessive in the environment along with rising fertilizer prices and stagnant crop prices, farmers and ranches strongly support improving nutrient use and agronomic efficiency in areas with both low soil productivity and other production constraint such as extended flooding. The different government agencies at the local, state, and federal levels along with fertilizer industry are under increasing pressure to improve nutrient use and agronomic efficiency. Roberts [7] reported that public interest and awareness of the need for improving nutrient efficiency is great, but nutrient use efficiency can be defined in many ways, and could be easily misunderstood and misrepresented.

Agronomic efficiency can be defined as the nutrients accumulated in the above-ground part of the plant or the nutrients recovered within the entire soil-crop-root system [7]. Raun and Johnson [8] defined $\mathrm{N}$ use efficiency as total $\mathrm{N}$ removed minus nutrient coming the soil and rainfall divided by the total $\mathrm{N}$ applied as a fertilizer material. Mosier et al. [9] described four agronomic indices commonly used to describe nutrient efficiency: partial factor productivity, which is $\mathrm{kg}$ crop yield per $\mathrm{kg}$ nutrient, applied; agronomic efficiency, which is crop yield increase per $\mathrm{kg}$ nutrient applied; apparent recovery efficiency, which is $\mathrm{kg}$ nutrient taken up per kg nutrient applied; and physiological efficiency, which is $\mathrm{kg}$ yield increase per kg nutrient taken up. Raun and Johnson [8] reported that under the present fertilizer use in the world, a single percent increase in the efficiency of $\mathrm{N}$ for cereal production worldwide would lead to about \$235 million savings in $\mathrm{N}$ fertilizer costs. An increase in nutrient use efficiency of $20 \%$ would result in a savings in excess of about $\$ 4.7$ billion per year. Another review of worldwide data on nutrient use efficiency for cereal crops from research-managed experimental plots reported that singleyear fertilizer $\mathrm{N}$ recovery efficiencies averaged $65 \%$ for corn, $57 \%$ for wheat and $46 \%$ for rice [10]. The average $\mathrm{N}$ recovery efficiency for fields managed by farmers ranges from about $20 \%$ to $30 \%$ under rainfed conditions and $30 \%$ to $40 \%$ under irrigated conditions [11].

The overall impact of adopting increased nutrient use efficiency in pasture-based cow-calf production may suggest that the environment would be less at risk and may increase production, reflecting the value of better stewardship. Knowing how $\mathrm{N}$ rate, grass species, and soil type affect apparent $\mathrm{N}$ recovery and $\mathrm{N}$ use efficiency could help producers reduce $\mathrm{N}$ losses into water resources and improve economic returns [12,13]. Donahue et al. [14] reported that the $\mathrm{N}$ use efficiency for orchardgrass was greatest at $247 \mathrm{~kg} \cdot \mathrm{N} \cdot \mathrm{ha}^{-1}$ while Long et al. [15] noted that the split $\mathrm{N}$ applications on ryegrass significantly increased $\mathrm{N}$ use efficiency only some of the time.

Research expansion especially production practices that would lead to an increase in nutrient use efficiency could be beneficial economically and environmentally safe for the beef cattle industry. Nitrogen use efficiency has been studied under a variety of field conditions for a wide array of grass species [14-19]. However, little is known about the response of forage species to the combined effect of waterlogging and the addition of nutrients. Forage species could be negatively affected by extended flooding and $\mathrm{N}$ application could offset the detrimental effect of flooding on $\mathrm{N}$ use efficiency and agronomic efficiency. While application of $\mathrm{N}$ to waterlogged plants decrease the deleterious effects, they do not fully overcome them [20,21], probably because of the reduced ability of roots to accumulate nitrate at low $\mathrm{O}_{2}$ levels [22, 23]. A two-year greenhouse study was conducted in 2008 and 2009 to determine i) the effect of flooding duration on $\mathrm{N}$ recovery and agronomic efficiency of bahiagrass compared with two flooding tolerant forages, limpograss, and maidencane and ii) if $\mathrm{N}$ fertilization could mitigate the negative effect of flooding. This study is a second paper from a series of papers about the effect of flooding duration and $\mathrm{N}$ fertilization on yield and productivity of three forage species.

\section{MATERIALS AND METHODS}

\subsection{Soil and Plants Preparation}

Soils needed for this study were obtained from a Blichton soil series (loamy, siliceous, hyperthermic, Arenic Paleaudults) at a depth of $0-20 \mathrm{~cm}$ using a backhoe from a pasture at the USDA-ARS Subtropical Agriculture Research Station (STARS), Brooksville, FL in 2008 and 2009. The soil was air dried outside on an impervious surface at USDA-NRCS Plant Material Center (PMC), Brooksville, FL. Prior to drying, eight to ten random samples were collected to determine selected physical and initial chemical properties (Table 1). Blichton soils are poorly drained soils, typical of south Florida with water table at a depth of less than $25 \mathrm{~cm}$ for cumulative periods of 1 to 4 months during most years. These soils, like many of the soils in south Florida, have argillic and spodic horizons.

The two introduced species of subtropical grasses, bahiagrass cv. Tifton-9 and limpograss cv. Floralta, and one native grass, maidencane cv. Citrus, were used in the study. All of the plant material was excavated from established stands ( $>5$-yr old) at either STARS or the PMC. Table 2 shows some selected plant characteristics and growth requirements for bahiagrass, limpograss, and maidencane. Approximately $15 \times 10 \mathrm{~cm}$ plugs consisting of crowns, rhizomes, and roots of each forage species (trimmed off to approx. 10-cm stubble height) were transplanted from the field 12 weeks prior to the initiation of the study each year. The plugs were planted into $15 \times 60 \mathrm{~cm}$ planting columns that have been filled to 
Table 1. Selected physical and chemical properties of soils used in the study.

\begin{tabular}{ccc}
\hline Soil Properties & Unit & Value \\
\hline Particle Size & & \\
Sand & $\mathrm{g} \cdot \mathrm{kg}^{-1}$ & 868 \\
Silt & $\mathrm{g} \cdot \mathrm{kg}^{-1}$ & 75 \\
Clay & $\mathrm{g} \cdot \mathrm{kg}^{-1}$ & 57 \\
Hydraulic Conductivity & $\mathrm{cm} \cdot \mathrm{hr}^{-1}$ & 7.0 \\
Bulk Density & $\mathrm{kg} \cdot \mathrm{m}^{-3}$ & 1.4 \\
CEC & $\mathrm{meq} \cdot 100 \cdot \mathrm{g}^{-1}$ & 11.2 \\
Ca & $\mathrm{mg} \cdot \mathrm{kg}^{-1}$ & 2.9 \\
$\mathrm{Mg}$ & $\mathrm{mg} \cdot \mathrm{kg}^{-1}$ & 0.5 \\
$\mathrm{Na}$ & $\mathrm{mg} \cdot \mathrm{kg}^{-1}$ & 0.1 \\
$\mathrm{~K}$ & $\mathrm{mg} \cdot \mathrm{kg}^{-1}$ & 0.1 \\
$\mathrm{pH}$ & & 5.5 \\
\hline
\end{tabular}

Table 2. Selected plant characteristics of the different forage species used in the study.

\begin{tabular}{llll}
\hline Plant Characteristics & Bahiagrass & Limpograss & Maidencane \\
\hline 1. Duration & Perennial & Perennial & Perennial \\
2. Growth Habit & Graminoid & Graminoid & Graminoid \\
3. Anaerobic Tolerance & Low & Medium & High \\
4. Drought Tolerance & High & Low & None \\
5. Fertility Requirement & High & High & Medium \\
6. Moisture Use & Low & High & High \\
7. pH, Minimum & 4.5 & 5.5 & 4.7 \\
8. pH, Maximum & 6.5 & 7.5 & 8.6 \\
9. Salinity Tolerance & Low & None & None \\
10. Shade Tolerance & Intermediate & Intolerant & Intermediate
\end{tabular}

within approximately $15 \mathrm{~cm}$ of the surface with the air dried, screened $(1 \times 1 \mathrm{~cm}$ screen $)$ soils from the A horizon of Blichton series. The planting columns were sealed at the bottom to control water movement through the column. A hole was drilled at the side of the column and fitted with a drain tube with a stopcock to allow draining and sampling of the soil solution.

\subsection{Greenhouse and Experimental Set-Up}

Immediately after planting, the columns with open drain tubes were moved into the greenhouse $\left(22^{\circ} \mathrm{C} / 32^{\circ} \mathrm{C}\right.$, $69 \%$ direct light) at the PMC and allowed to recover and grow during the $12 \mathrm{wk}$ pretrial period. During the first four weeks of the pretrial period, the plants were fertilized with a soluble complete fertilizer equivalent to 23 $\mathrm{kg}$ total of $\mathrm{N}, \mathrm{P}$, and $\mathrm{K}$, and then fertilization discontinued. During the remainder of the adjustment periods (12 weeks), the plants were watered as needed to maintain the soil moisture approximately at field capacity.

Experimental treatments were replicated five times using a $3 \times 5 \times 3$ split-split plot arrangement in com- pletely randomized block design. Forage types were the main treatment effect while flooding duration and $\mathrm{N}$ levels were the sub-plots features of a two-year greenhouse study conducted in 2008 and 2009, respectively. All columns received $40 \mathrm{~kg} \cdot \mathrm{ha}^{-1}$ of $\mathrm{P}$ as triple super phosphate granular fertilizer and appropriate $\mathrm{N}$ levels consisted of 0,100 , and $200 \mathrm{~kg} \cdot \mathrm{ha}^{-1}$ of $\mathrm{N}$ as $\mathrm{NH}_{4} \mathrm{NO}_{3}$ were applied to the appropriate columns for each forage species. Ammonium nitrate fertilizer $(34 \% \mathrm{~N})$ was used in the study because it is commonly used as a source for $\mathrm{N}$ in blends and applied directly to pastures. Historically, ammonium nitrate has been a major $\mathrm{N}$ source used on pastures in the USA. Although ammonium nitrate is extremely soluble in water, under normal conditions of storage, it is stable. When applied at adequate rates, it does not produce as much acidity as other $\mathrm{N}$ fertilizer sources. In addition it has a salt index of 2.99. This value indicates that the chances of ammonium nitrate to cause burning problems in the pastures are limited.

The soil flooding duration was consisted of $0-, 14-$, 28-, 56-, and 84-d to mimic flooding occurrences in south Florida that may be associated with the need to store rainfall on pastureland during summer in Florida. Flooding treatments were staggered such that termination of all flooding duration times coincided with the maximum flooding time of $84 \mathrm{~d}$. For plants not receiving flood treatment, soil moisture was maintained at soil field capacity limit. Until a flooding treatment was started, all drain tubes remained open and the treatments were watered.

\subsection{Dry Matter Yield and Tissue Analysis}

All treatments were destructively sampled at the end of maximum flooding time treatment of $84 \mathrm{~d}$. Freshly cut aboveground biomass was oven-dried at $60^{\circ} \mathrm{C}$ for 24 hours at the USDA-ARS Laboratory in Brooksville, FL. Plant samples were ground to pass through a $1-\mathrm{mm}$ mesh screen in a Wiley mill. Ground forage was analyzed for total Kjeldahl N concentration [24] at the University of Florida Analytical Research Laboratory, Gainesville, FL. All the needed protocols and measurements for dry matter yield and tissue analysis were performed in similar fashion during the 2008 and 2009 cropping/harvest season, respectively.

\subsection{Agronomic Efficiency and Nitrogen Recovery}

The $\mathrm{N}$ recovery and agronomic efficiency of bahiagrass, limpograss, and maidencane were calculated using the equations as defined below.

$$
\begin{aligned}
& \text { Nitrogen Recovery }(\%) \\
& =[(\mathrm{NUF}-\mathrm{NUNF}) / \mathrm{AFA}] \times 100
\end{aligned}
$$




$$
\begin{aligned}
& \text { Agronomic Efficiency (\%) } \\
& =[(\mathrm{DMY}-\mathrm{FDMYNF}) / \mathrm{AFA}] \times 100
\end{aligned}
$$

where: NUF $\left(\mathrm{kg} \cdot \mathrm{N} \cdot \mathrm{ha}^{-1}\right)-\mathrm{N}$ uptake of forage fertilized with 100 and $200 \mathrm{~kg} \cdot \mathrm{N} \cdot \mathrm{ha}^{-1}$;

NUNF $\left(\mathrm{kg} \cdot \mathrm{N} \cdot \mathrm{ha}^{-1}\right)-\mathrm{N}$ uptake of forage at $0 \mathrm{~kg} \cdot \mathrm{N} \cdot \mathrm{ha}^{-1}$; DMYF $\left(\mathrm{kg} \cdot \mathrm{ha}^{-1}\right)$ _ yield of forage fertilized with 100 and $200 \mathrm{~kg} \cdot \mathrm{N} \cdot \mathrm{ha}^{-1}$;

DMYNF $\left(\mathrm{kg} \cdot \mathrm{ha}^{-1}\right)$ - yield of forage at $0 \mathrm{~kg} \cdot \mathrm{N} \cdot \mathrm{ha}^{-1}$; and AFA $\left(\mathrm{kg} \cdot \mathrm{N} \cdot \mathrm{ha}^{-1}\right)$ _amount of fertilizer applied (100 $\left.\mathrm{kg} \cdot \mathrm{N} \cdot \mathrm{ha}^{-1} ; 200 \mathrm{~kg} \cdot \mathrm{N} \cdot \mathrm{ha}^{-1}\right)$.

\subsection{Redox Potential Measurements}

Reduction-oxidation (redox) potential of the soil solution was determined in 2008 (June 22 to September 4) and in 2009 (June 23 to September 5) to monitor anaerobic condition of soils under varying soil wetness. The redox potentials are reported as the average of two-year (2008-2009) study. Soil redox potential measurements have been used to characterize the intensity of reduction and oxidation and relate this to biological processes occurring in flooded soils. Our measurement of redox potentials was based on methods described by Patrick et al. [25]. Measurement equipment consisted of three pieces of equipment: platinum electrode, reference electrode, and voltmeter. The platinum electrode and the reference electrode (calomel: $\mathrm{Ag} / \mathrm{AgCl}$ ) were both buried into the soil column ( $7-10 \mathrm{~cm}$ depths) to be in contact with the soil solution. Wires from both the platinum electrode and reference electrode were connected to a voltmeter. The redox potential was adjusted to the standard redox potential (Eh) by adding a value of +245 to the voltmeter reading.

\subsection{Statistical Analysis}

The effects of flooding and $\mathrm{N}$ application on $\mathrm{N}$ recovery and agronomic efficiency of three forage species in 2008 and 2009 (pooled), respectively, were analyzed statistically following the PROC GLM procedures [26]. Where the F-test indicated a significant $(P \leq 0.05)$ effect, means were separated, following the method of Duncan Multiple Range test, using appropriate mean squares [26]. For F-test results that were highly significant, means were separated using LSD test [26]. Data collected in 2008 and 2009 were pooled; therefore, year effect was excluded in the data analyses [26].

\section{RESULTS AND DISCUSSION}

\subsection{Effects on Nitrogen Recovery}

Nitrogen recovery was affected $(P \leq 0.01)$ by the interaction effect of flooding duration and levels of $\mathrm{N}$ (Table 3). The greatest $\mathrm{N}$ recovery for bahiagrass of $73.8 \%$ was from the control tube ( 0 day flooding) that was fertilized with $200 \mathrm{~kg} \cdot \mathrm{N} \cdot \mathrm{ha}^{-1}$ while the least amount of $\mathrm{N}$ recovery $(22.4 \%)$ was from tube that was flooded for 84 $\mathrm{d}$ and fertilized with $100 \mathrm{~kg} \cdot \mathrm{N} \cdot \mathrm{ha}^{-1}$ (Table 3). The least amount of $\mathrm{N}$ recovery for limpograss $(18.2 \%)$ was from the flooded tube for $84 \mathrm{~d}$ with $\mathrm{N}$ application of 200 $\mathrm{kg} \cdot \mathrm{N} \cdot \mathrm{ha}^{-1}$ while the greatest $\mathrm{N}$ recovery $(74.1 \%)$ was from the control tube with $100 \mathrm{~kg} \cdot \mathrm{N} \cdot \mathrm{ha}^{-1}$ (Table 3). The greatest amount of $\mathrm{N}$ recovery for maidencane of $64.2 \%$ was from the flooded tube for $14 \mathrm{~d}$ with $100 \mathrm{~kg} \cdot \mathrm{N} \cdot \mathrm{ha}^{-1}$ fertilization. Although these results are suggesting that $\mathrm{N}$ recovery of the three forage species was hampered by flooding duration, it had been significantly enhanced with $\mathrm{N}$ fertilization.

Our results support our hypothesis that the negative impact of flooding could be mitigated by $\mathrm{N}$ fertilization. This claim was exhibited by a much higher $\mathrm{N}$ recovery under any flooding duration of plants that received higher $\mathrm{N}$ application as opposed to those plants without $\mathrm{N}$ fertilization at any given flooding duration. Averaged across flooding treatment, the overall $\mathrm{N}$ recovery of bahiagrass, limpograss, and maidencane ranged from $44.1 \%$ to $58.7 \%$ (Figure 1). Bahiagrass fertilized with 100 and $200 \mathrm{~kg} \cdot \mathrm{N} \cdot \mathrm{ha}^{-1}$ recovered about $47.8 \%$ and $54.3 \%$ of $\mathrm{N}$, respectively over the non-fertilized plants. About $44.1 \% \mathrm{~N}$ was recovered by limpograss over the non-fertilized plants while maidencane recovery was $58.7 \%$ and $51.2 \%$ at 100 and $200 \mathrm{~kg} \cdot \mathrm{N} \cdot \mathrm{ha}^{-1}$, respectively (Figure 1).

The effect of flooding duration on $\mathrm{N}$ recovery of bahiagrass, limpograss, and maidencane that were fertilized with $100 \mathrm{~kg} \cdot \mathrm{N} \cdot \mathrm{ha}^{-1}$ was comparable with the $\mathrm{N}$ recovery of bahiagrass, limpograss, and maidencane that were fertilized at $200 \mathrm{~kg} \cdot \mathrm{N} \cdot \mathrm{ha}^{-1}$ (Table 3). Comparable $\mathrm{N}$ recovery between plants fertilized at 100 and $200 \mathrm{~kg} \cdot \mathrm{N} \cdot \mathrm{ha}^{-1}$ could be attributed to the inability of flooded plants to accumulate higher $\mathrm{N}$ because active accumulation of $\mathrm{N}$ by roots was impaired as suggested by Spek [22]. Nitrogen recovery of forage species after $84 \mathrm{~d}$ of flooding that were fertilized with $100 \mathrm{~kg} \cdot \mathrm{N} \cdot \mathrm{ha}^{-1}$ was in the following order: maidencane $(55.3 \%)>$ limpograss $(36.7 \%)>$ bahiagrass $(22.4 \%)$. However, the order of $\mathrm{N}$ recovery for the three forage species fertilized with $200 \mathrm{~kg} \cdot \mathrm{N} \cdot \mathrm{ha}^{-1}$ was as follows: maidencane $(50.1 \%)>$ bahiagrass $(41.3 \%)>$ limpograss $(18.2 \%)$. Our results show that the three forage species have the ability to tolerate waterlogging is a tool not only to survive in such environment, but also to respond to a growth stimulating factor, such as $\mathrm{N}$ fertilization. This suggests that the effects of flooding may be cumulative over time. Differences in $\mathrm{N}$ recovery among the three forage species as affected by $\mathrm{N}$ fertilization can be considered an adaptation to improve their nutrient uptake efficiency [27,28]. Forage species vary in their ability to withstand flooding and this undoubtedly con- 
Table 3. Nitrogen recovery (\%) of bahiagrass, limpograss, and maidencane as affected by $\mathrm{N}$ fertilization under flooded conditions.

\begin{tabular}{|c|c|c|c|c|}
\hline Flooding Duration (days) & Nitrogen $\left(\mathrm{kg}^{\prime} \cdot \mathrm{ha}^{-1}\right)$ & Bahiagrass & Limpograss & Maidencane \\
\hline & 0 & - & - & - \\
\hline \multirow[t]{2}{*}{$\mathbf{0}$} & 100 & 34.5 & 74.1 & 50.0 \\
\hline & 200 & 73.8 & 50.7 & 49.6 \\
\hline \multirow[t]{2}{*}{ Mean } & & 54.2 & 62.4 & 49.8 \\
\hline & $\mathbf{0}$ & - & - & - \\
\hline \multirow[t]{2}{*}{14} & 100 & 66.2 & 53.5 & 64.2 \\
\hline & 200 & 67.5 & 36.1 & 43.3 \\
\hline \multirow[t]{2}{*}{ Mean } & & 66.8 & 44.8 & 53.8 \\
\hline & $\mathbf{0}$ & - & - & - \\
\hline \multirow[t]{2}{*}{28} & 100 & 58.7 & 52.2 & 60.3 \\
\hline & 200 & 54.4 & 69.0 & 61.8 \\
\hline \multirow[t]{2}{*}{ Mean } & & 56.6 & 60.6 & 61.1 \\
\hline & $\mathbf{0}$ & - & - & - \\
\hline \multirow[t]{2}{*}{56} & 100 & 23.2 & 38.6 & 60.3 \\
\hline & 200 & 54.2 & 46.3 & 51.3 \\
\hline \multirow[t]{2}{*}{ Mean } & & 38.7 & 42.4 & 55.8 \\
\hline & $\mathbf{0}$ & - & - & - \\
\hline \multirow[t]{2}{*}{84} & 100 & 22.4 & 36.7 & 55.3 \\
\hline & 200 & 41.3 & 18.2 & 50.1 \\
\hline Mean & & 31.8 & 27.4 & 52.2 \\
\hline \multicolumn{5}{|l|}{$\underline{\text { Sources of Variations }}$} \\
\hline Plant (P) & & & ${ }^{* * *}$ & \\
\hline Flooding $(\mathrm{F})$ & & & $* *$ & \\
\hline Nitrogen $(\mathrm{N})$ & & & ${ }^{* * *}$ & \\
\hline $\mathrm{P} \times \mathrm{F}$ & & & $\mathrm{ns}$ & \\
\hline $\mathrm{P} \times \mathrm{N}$ & & & ns & \\
\hline $\mathrm{F} \times \mathrm{N}$ & & & $*$ & \\
\hline $\mathrm{P} \times \mathrm{F} \times \mathrm{N}$ & & & ns & \\
\hline
\end{tabular}

ns—not significant; ${ }^{* * *}$ - significant at $P \leq 0.0001 ;{ }^{* *}$ - significant at $P \leq 0.001 ;{ }^{*}$ - significant at $P \leq 0.01$.

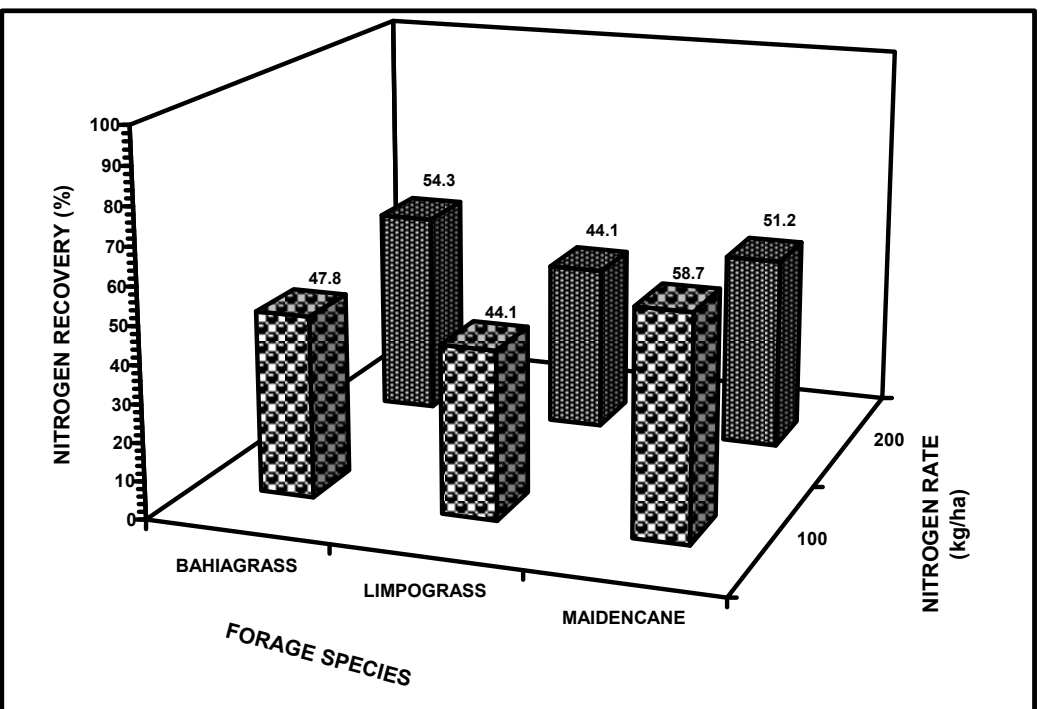

Figure 1. Nitrogen recovery of three forage species as affected by flooding duration at different levels of $\mathrm{N}$ fertilization. 
tributes to their ecological distribution [29]. There are two distinctly different strategies that plants employ to survive flooding: tolerance of anoxia and avoidance of anoxia. Anoxia tolerance involves metabolic adaptation and varies among species, plants, and tissues. Anoxia avoidance requires the development of mechanisms to deliver oxygen to the roots through internal channels.

The uptake of $\mathrm{N}$ by plants under waterlogged conditions is consequence of the effect of aeration on the physiological processes, such as decrease in root permeability, respiratory activity of the plants, and the chemical changes in the soil [30]. Flooding of the soil surface caused an immediate increase in volumetric water content at the cost of displacing air and therefore $\mathrm{O}_{2}$ from the soil profile [23]. The decrease in $\mathrm{O}_{2}$ following flooding could be expected to reduce the rate of root growth. Quite crucial to the interpretation of our results is the limited amount of oxygen that may be present following flooding. Oxygen level was indirectly measured using the redox. Redox potential is an electrical measurement that shows the tendency of a soil solution to transfer electrons to or from a reference electrode. This measurement can estimate whether the soil is fully or partly aerobic or in anaerobic condition. Figure 2 shows the different levels of redox potential readings from soils that were flooded from 0 to $84 \mathrm{~d}$. Except for the non-flooded (control) soils, all the soils attained the stage of anaerobic conditions between $8-10 \mathrm{~d}$ and became fully anaerobic thereafter. An Eh reading below $0 \mathrm{mV}$ would mean limited supply of oxygen in the soil. It is generally accepted that energy deficit is one of the most severe problems encountered by plants when subjected to flooding. Oxygen is the terminal acceptor of electrons in the oxidative phosphorylation that indirectly provides the plant with ATP [31].

Although flooding typically causes a reduction in the abundance of flood-sensitive plant species, it can also promote $\mathrm{N}$ uptake and biomass growth in flood-tolerant species to exploit resources that otherwise would be shared with non-tolerant competitors $[32,33]$. The three forage species in our study may have the capacity for regulating leaf water and carbon relations under highly changing atmospheric conditions. Voesenek et al. [31] suggested that hormonal effects were involved in growth response for plants under waterlogged conditions because photosynthesis rates could be enhanced by increased leaf temperature at higher air vapor pressure deficit in most $\mathrm{C}_{4}$ grasses while differences in photosynthetic activities between flooded and control plants may be accounted for by the differences in stomatal conductance.

Recent studies in grasslands of Argentina found that native grasses present slight growth tolerant responses to flooding, such as aerenchyma tissue formation and increase in plant height [6,34]. Aerenchyma formation and leaf elongation are important for the recovery of contact with aerial environment and allow oxygen transport to the submerged tissues of native grasses [35,36]. Plants that adopt this mechanism have modified patterns of growth and are not necessarily tolerant to low atmospheric oxygen levels [4]. Other plants possess the ability to develop a combination of mechanisms enabling them to grow under waterlogged conditions [37]. Anaerobic conditions inhibit almost immediately the transport of $\mathrm{N}$ ions by roots [38]. This may be due to insufficient energy to maintain the activity of ion pumps. Phloem unloading

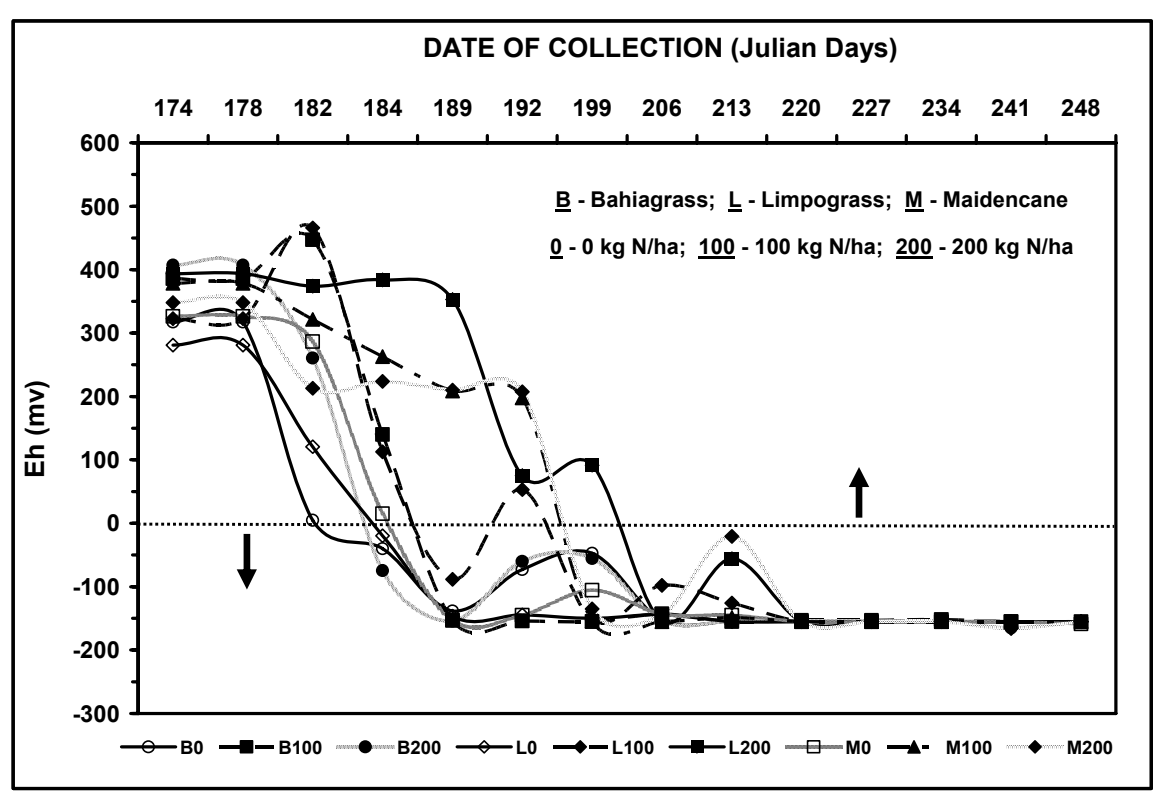

Figure 2. Average levels of reduction-oxidation (Eh) readings during the flooding experiment. 
in the anaerobic root ceases and transport of metabolites and growth regulators between the root and shoot are therefore impeded.

\subsection{Effects on Agronomic Efficiency}

Agronomic efficiencies of forage specie varied widely $(P \leq 0.01)$ and were significantly affected by the interaction effects of flooding duration and levels of $\mathrm{N}$ (Table 4). Agronomic efficiencies of forage species were also significantly affected by the main treatment effects (flooding duration, $P \leq 0.001$ and levels of $\mathrm{N}, P \leq 0.001$ ). The greatest agronomic efficiency for bahiagrass (49.3\%) was from $14 \mathrm{~d}$ flooding with $100 \mathrm{~kg} \cdot \mathrm{N} \cdot \mathrm{ha}^{-1}$. The highest amount of agronomic efficiency for limpograss (55.9\%) was from plants flooded for $28 \mathrm{~d}$ with $200 \mathrm{~kg} \cdot \mathrm{N} \cdot \mathrm{ha}^{-1}$. The greatest amount of agronomic efficiency for maidencane $(58.9 \%)$ was from plants flooded for $56 \mathrm{~d}$ with 200 $\mathrm{kg} \cdot \mathrm{N} \cdot \mathrm{ha}^{-1}$. Averaged across $\mathrm{N}$ levels, agronomic efficiency of bahiagrass declined from $40.6 \%$ to $25.5 \%$ after $84 \mathrm{~d}$ of continued flooding while agronomic efficiency for limpograss had declined from $44.2 \%$ to $31.4 \%$ after $84 \mathrm{~d}$ of flooding treatment. Agronomic efficiency for maidencane was not negatively affected by flooding treatment because agronomic efficiency had increase from $24.2 \%$ ( $0 \mathrm{~d}$ flooding) to $46.4 \%$ after $84 \mathrm{~d}$ of continuous flooding (Table 4).

It appears that forage plants, except for limpograss that were fertilized with $200 \mathrm{~kg} \cdot \mathrm{ha}^{-1}$ of $\mathrm{N}$ had higher agro-

Table 4. Agronomic efficiency (\%) of bahiagrass, limpograss, and maidencane as affected by $\mathrm{N}$ fertilization under flooded conditions.

\begin{tabular}{|c|c|c|c|c|}
\hline Flooding Duration (days) & Nitrogen $\left(\mathrm{kg} \cdot \mathrm{ha}^{-1}\right)$ & Bahiagrass & Limpograss & Maidencane \\
\hline & $\mathbf{0}$ & - & - & - \\
\hline \multirow[t]{2}{*}{$\mathbf{0}$} & 100 & 46.2 & 51.5 & 22.0 \\
\hline & 200 & 35.0 & 36.8 & 26.4 \\
\hline \multirow[t]{2}{*}{ Mean } & & 40.6 & 44.2 & 24.2 \\
\hline & $\mathbf{0}$ & - & - & - \\
\hline \multirow[t]{2}{*}{14} & 100 & 49.3 & 38.0 & 19.6 \\
\hline & 200 & 30.5 & 32.0 & 22.9 \\
\hline \multirow[t]{2}{*}{ Mean } & & 39.9 & 35.0 & 21.2 \\
\hline & $\mathbf{0}$ & - & - & - \\
\hline \multirow[t]{2}{*}{28} & 100 & 32.0 & 48.5 & 22.0 \\
\hline & 200 & 26.5 & 55.9 & 29.9 \\
\hline \multirow[t]{2}{*}{ Mean } & & 29.2 & 52.2 & 25.9 \\
\hline & $\mathbf{0}$ & - & - & - \\
\hline \multirow[t]{2}{*}{56} & 100 & 33.1 & 50.5 & 58.9 \\
\hline & 200 & 17.2 & 44.2 & 29.6 \\
\hline \multirow[t]{2}{*}{ Mean } & & 25.2 & 47.4 & 44.2 \\
\hline & $\mathbf{0}$ & - & - & - \\
\hline \multirow[t]{2}{*}{84} & 100 & 31.2 & 36.6 & 47.3 \\
\hline & 200 & 19.8 & 26.3 & 45.4 \\
\hline Mean & & 25.5 & 31.4 & 46.4 \\
\hline \multicolumn{5}{|l|}{ Sources of Variations } \\
\hline Plant $(\mathrm{P})$ & & & $* * *$ & \\
\hline Flooding $(\mathrm{F})$ & & & ** & \\
\hline Nitrogen $(\mathrm{N})$ & & & $* * *$ & \\
\hline $\mathrm{P} \times \mathrm{F}$ & & & $* * *$ & \\
\hline $\mathrm{P} \times \mathrm{N}$ & & & ns & \\
\hline $\mathrm{F} \times \mathrm{N}$ & & & ${ }^{*}$ & \\
\hline $\mathrm{P} \times \mathrm{F} \times \mathrm{N}$ & & & ns & \\
\hline
\end{tabular}

ns - not significant; ${ }^{* * *}$ - significant at $P \leq 0.0001 ;{ }^{* *}$ - significant at $P \leq 0.001 ;{ }^{*}$ - significant at $P \leq 0.01$. 
nomic efficiency when compared to those plants with $100 \mathrm{~kg} \cdot \mathrm{ha}^{-1}$ of applied $\mathrm{N}$ under any flooding duration (Figure 3). The agronomic efficiency for bahiagrass was $42.8 \%$ and $57.7 \%$ at 100 and $200 \mathrm{~kg} \cdot \mathrm{N} \cdot \mathrm{ha}^{-1}$. Limpograss efficiency had declined from $55.0 \%$ to $39.1 \%$ between 100 and $200 \mathrm{~kg} \cdot \mathrm{N} \cdot \mathrm{ha}^{-1}$ while agronomic efficiency for maidencane showed significant from $30.9 \%$ to $33.9 \%$ due to application of $100 \mathrm{~kg} \cdot \mathrm{N} \cdot \mathrm{ha}^{-1}$ and $200 \mathrm{~kg} \cdot \mathrm{N} \cdot \mathrm{ha}^{-1}$, respectively. These results again support the hypothesis of the study on the offsetting effect of $\mathrm{N}$ on the detrimental effect of flooding on agronomic efficiency. The use of $\mathrm{N}$ fertilizer prior to flooding may alleviate $\mathrm{N}$ deficiency because waterlogging causes a significant decrease in $\mathrm{N}$ content and rate of $\mathrm{N}$ accumulation in plants due to reduced root activity. Net assimilation rates and photosynthetic rates decline in plants experiencing root anaerobiosis, in part due to stomatal closure, and in part due to biochemical modifications [4].

The effect of $\mathrm{N}$ fertilization on agronomic efficiency is shown in Table 4. These results are likely to be a forage species response. The individual genetic composition and metabolic behavior for each species of forage would have an influence on these results. Differences in agronomic efficiencies among the three forage species as affected by $\mathrm{N}$ fertilization can be considered an adaptation to improve their $\mathrm{N}$ uptake efficiency, and possibly may have had affected crude protein formation [27,28]. Nitrogen fertilization of pasture forages generally increases digestibility. Early reports [39-42] claimed that on bermudagrass pastures, crude protein content of the forage increased with each increment in $\mathrm{N}$ fertilization up to $504 \mathrm{~kg} \cdot \mathrm{ha}^{-1}$.
Our results were similar to the early findings of Rubio et al. [6] who reported that the nutrient demand of water logging tolerant plants is supposed to be high under soil anoxia because plants are able to maintain or even increase their biomass production and nutrient uptake efficiency. Rubio et al. [6] observed a reduction in root: shoot ratio of two grasses (Paspalum dilatatum and Danthonia montevidensis) caused by waterlogging did not have a cost in terms of capacity for nutrient uptake. Reduction in root growth and shoot elongation may cause a decrease in root carbohydrate demand, which may be one cause of reduced photosynthate transport to flooded roots [43]. As observed, agronomic efficiency of forage species in our study was positively affected by $\mathrm{N}$ fertilization despite the anoxic environment and these results may be explained by sufficient nutrients that compensated for the negative effect of waterlogging (Table 4). This observation is consistent with the findings of Meyer et al. [23] who reported that plants with high levels of $\mathrm{N}$ under waterlogged condition had more efficient photosynthetic mechanism with increase stomatal function. Earlier findings of Chapin [44] also showed that nutrient-rich environments, root systems can satisfy plant nutrient requirements resulting in normal metabolic activities of plants. The published report of Sigua and Hudnall [45] confirmed the importance of gypsum and $\mathrm{N}$ fertilization on productivity and yield of four species of wetland vegetation under saline environment. Their results disclosed highly significant protein content responses to gypsum and $\mathrm{N}$ additions. Increased growth, yield, and protein content were observed from the fertilized plants.

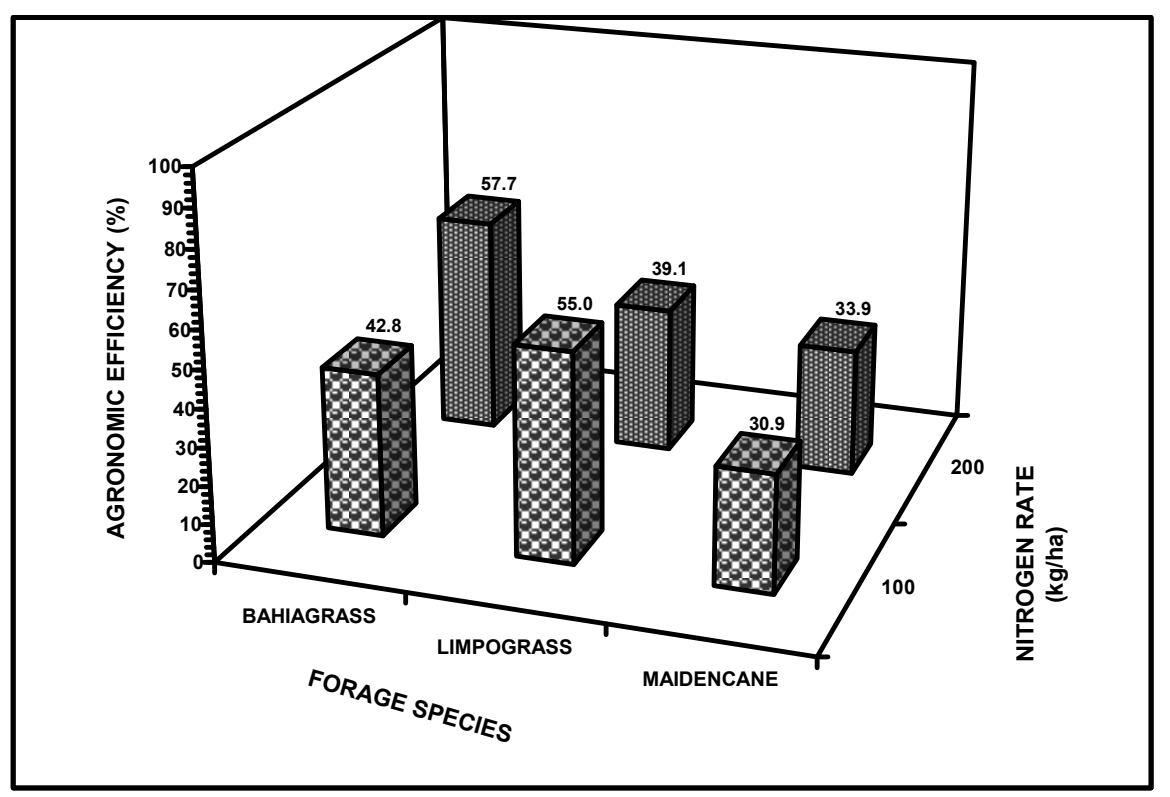

Figure 3. Agronomic efficiency of three forage species as affected by flooding duration at different levels of $\mathrm{N}$ fertilization. 
Nitrogen is typically the main limiting nutrient and important agronomic input for the production of forages and use of $\mathrm{N}$ fertilizers is vital for the sustained productivity of bahiagrass, limpograss, and maidencane especially under flooded condition. The use efficiency of this fertilizer $\mathrm{N}$ by forage is typically low, due in part to losses of the applied fertilizer because of unique features of submerged soils as compared to aerated soils. Submerged soils as compared with aerated soils are favorable environments for loss of $\mathrm{N}$ by nitrification-denitrification. Since we used ammoniacal fertilizer $\left(\mathrm{NH}_{4} \mathrm{NO}_{3}\right)$, the rate of nitrification is a key determinant of $\mathrm{N}$ losses (no data to show). The nitrate ions are substrate for denitrification, thus nitrification acts as a key process in determining fertilizer-use efficiency by crops, $\mathrm{N}$ recovery, as well as $\mathrm{N}$ losses from soils [46].

Actual measurement of $\mathrm{N}$ losses was not part of our study. Very limited information is available on the direct measurements of $\mathrm{N}$ losses via denitrification. Severe $\mathrm{N}$ losses have been shown to occur in soils subjected to periods of alternate drained (aerobic) and flooded (anaerobic) conditions [47-50]. Wijler and Delwiche [47] noted that alternating aerobic and anaerobic conditions should result in greater total $\mathrm{N}$ loss from the soil than would be found under continuous anaerobic conditions. Patrick and Wyatt [49] observed large losses of N (up to $20 \%$ of total N) as a result of repeated cycles of flooding and drying to field moisture. Tusneem and Patrick [51] showed that ammonium $\mathrm{N}$ was highly unstable under alternate flooded and moist conditions of several weeks' duration.

Based on the results reported by Wijler and Delwiche [47] and Tusneem and Patrick [51], the use of ammonium nitrate fertilizer for forage under flooded pasture (this study) was not really bad at all despite of $\mathrm{N}$ losses via denitrification. Although we have no data to show the actual magnitude of $\mathrm{N}$ denitrification, our results somehow had been affected. Ammonium nitrate fertilizer was used in the study because it is commonly used as a source for $\mathrm{N}$ in blends and applied directly to pastures if $\mathrm{N}$ was the only nutrient being applied. When applied at adequate rates, ammonium nitrate does not produce as much acidity as other $\mathrm{N}$ fertilizer sources (i.e., ammonium sulfate). Again, the use of $\mathrm{N}$ fertilizers can be used and is vital for the sustained productivity of bahiagrass, limpograss, and maidencane especially under flooded condition. However, denitrification remains a significant $\mathrm{N}$ loss pathway in flooded condition and certainly would affect agronomic efficiency and $\mathrm{N}$ recovery.

\section{SUMMARY AND CONCLUSIONS}

To determine the potential ecological impact of periodic flooding on plant growth and protein content, three species of subtropical grasses: "Tifton 9" bahiagrass;
"Floralta" limpograss; and "Citrus" maidencane were evaluated under differing flooding durations and levels of $\mathrm{N}$ fertilization under greenhouse conditions in 2008 and 2009. The overall results and observations in this study could be briefly summarized as follows:

1) Despite reductions in biomass, $\mathrm{N}$ recovery, and agronomic efficiency, and reduction in $\mathrm{N}$ uptake, all the three forage species were able to survive $84 \mathrm{~d}$ of flooding and performed like facultative hydrophypyte specie under soil flooding;

2) Agronomic efficiencies of bahiagrass (41\% to 26\%) and limpograss (44\% to $31 \%$ ) were reduced by flooding while agronomic efficiency of maidencane was increased from $24 \%$ (no flooding) to $46 \%$ at $84 \mathrm{~d}$ of continued flooding; and

3) Nitrogen recovery and agronomic efficiency of three forage species were positively affected by $\mathrm{N}$ fertilization. The overall $\mathrm{N}$ recovery of bahiagrass, limpograss, and maidencane ranged from $44 \%$ to $59 \%$.

The overall results reported in this paper were consistent with the findings in the early paper of Sigua et al. [52] who reported that the overall yield response and crude protein content of bahiagrass, limpograss, and maidencane were linearly related to increasing levels of $\mathrm{N}$ fertilization. A much higher biomass and crude protein content under any flooding duration of three forage species that received higher $\mathrm{N}$ fertilization as opposed to those plants without $\mathrm{N}$ fertilization. Therefore, results reported in this paper and the early paper support the hypotheses of negative impact of extended flooding on biomass, crude protein content, nutrient recovery, and agronomic efficiency of bahiagrass, limpograss, and maidencane could be mitigated by $\mathrm{N}$ fertilization.

Given the current state of knowledge from this study, additional work needs to be done at least on two research areas: 1) $\mathrm{N}$ budgets need to be prepared under different frequency of flooding. These should take into account various $\mathrm{N}$ inputs (atmospheric deposition, $\mathrm{N}$ fixation, $\mathrm{N}$ fertilization) and output via crop removal and losses through mechanisms like ammonia volatilization, nitrification-denitrification, and leaching; and 2) Better understanding of rate limiting steps for different $\mathrm{N}$ transformation processes controlling losses of $\mathrm{N}$.

\section{REFERENCES}

[1] Wortmann, C.S., Tarkalson, D.D., Shapiro, C.A., Dobermann, A.R., Ferguson, R.B., Hergert, G.W. and Walters, D. (2011) Nitrogen use efficiency of irrigated corn for three cropping systems in Nebraska. Agronomy Journal, 103 76-84. doi:10.2134/agronj2010.0189

[2] Drew, M.C., Sisworo, E.J. and Saker, L.R. (1979) Alleviation of waterlogging damage to young barley plants by application of nitrate and synthetic cytokinin. New. Phytologist, 82, 315-329. 
doi:10.1111/j.1469-8137.1979.tb02657.x

[3] Hodgson, A.S. (1982) The effects of duration, timing and chemical amelioration of short-term waterlogging during furrow irrigation of cotton in cracking gray soil. Australian Journal of Agricultural Research, 33, 1019-1028. doi:10.1071/AR9821019

[4] Jackson, M.B. and Drew M.C. (1984) Effects of flooding on growth and metabolism of herbaceous plants. In: Kozlowski, E.T., Ed., Flooding and Plant Growth, Academic Press, Orlando, 47-128.

[5] Naidoo, G. and Mundree, S.G. (1993) Relationship between morphological and physiological responses to waterlogging and salinity in Sporobolus virginicus (L). Oecologia, 93, 360-366. doi:10.1007/BF00317879

[6] Rubio, G., Casasola, G. and Lavado, R.S. (1995) Adaptation and biomass production of two grasses in response to waterlogging and soil nutrient enrichment. Oecologia, 102, 102-105.

[7] Roberts, T.L. (2008) Improving nutrient use efficiency. Turkish Journal of Agriculture and Forestry, 32, 177-182.

[8] Raun, W.R. and Johnson, G.V. (1999) Improving nitrogen use efficiency for cereal production. Agronomy Journal, 91, 357-363.

doi:10.2134/agronj1999.00021962009100030001x

[9] Mosier, A.R., Syers, K.K. and Freney, J.R. (2004) Agriculture and the nitrogen cycle. Assessing the impacts of fertilizer use on food production and the environment. Scope-65. Island Press, London, 150.

[10] Ladha, J.K., Pathak, H., Krupnik, T.J., Six, J. and van Kessel, C. (2005) Efficiency of fertilizer nitrogen in cereal production: Retrospect and prospects. Advances in Agronomy, 87, 85-156. doi:10.1016/S0065-2113(05)87003-8

[11] Cassman, K.G., Dobermann, A. and Walters, D.T. (2002) Agroecosystems, nitrogen use efficiency and nitrogen management. AMBIO, 31, 132-140.

[12] Zemenchik, R.A. and Albrecht, K.A. (2002) Nitrogen use efficiency and apparent nitrogen recovery of Kentucky bluegrass, smooth bromegrass, and orchardgrass. Agronomy Journal, 94, 421-428. doi:10.2134/agronj2002.0421

[13] Wright, M.J. and Davidson, K.L. (1964) Nitrate accumulation in crops and nitrate poisoning in animals. Advances in Agronomy, 16, 197-247. doi:10.1016/S0065-2113(08)60025-5

[14] Donahue, S.J., Rhykerd, C.L., Holt, D.A. and Noller, C.H. (1965) Influence of $\mathrm{N}$ fertilization and $\mathrm{N}$ carryover on yield and $\mathrm{N}$ concentration of Dactylis glomerata L. Agronomy Journal, 57, 671-674.

[15] Long, F.N.J., Kennedy, S.J. and Gracey, H.I. (1991) Effect of fertilizer nitrogen rate and timing on herbage production and nitrogen use efficiency for first-cut silage. Grass and Forage Science, 46, 231-237. doi:10.1111/j.1365-2494.1991.tb02228.x

[16] Drake, M., Colby, W.G. and Bredakis, E. (1963) Yield of orchardgrass as influenced by rates of nitrogen and harvest management. Agronomy Journal, 55, 361-362. doi:10.2134/agronj1963.00021962005500040018x

[17] George, J.R., Rhykerd, C.L., Noller, C.H., Dillon, J.E. and Burns, J.C. (1973) Effect of $\mathrm{N}$ fertilization on dry matter, total-N, N recovery, and nitrate- $\mathrm{N}$ concentration of three cool-season forage grass species. Agronomy Journal, 65, 211-216. doi:10.2134/agronj1973.00021962006500020008x

[18] Stout, W.L. and Jung, G.A. (1992) Influence of soil environment on biomass and nitrogen accumulation rates of orchardgrass. Agronomy Journal, 84, 1011-1019. doi:10.2134/agronj1992.00021962008400060021x

[19] Guillard, K., Griffin, G.F., Allinson, D.W., Rafey, M.M., Yamartino, W.R. and Pietrzyk, S.W. (1995) Nitrogen utilization of selected cropping systems in the US Northeast: Dry matter yield, $\mathrm{N}$ uptake, apparent $\mathrm{N}$ recover, and $\mathrm{N}$ use efficiency. Agronomy Journal, 87, 193-199. doi:10.2134/agronj1995.00021962008700020010x

[20] Shalhevet, J. and Zwerman, P.J. (1962) Nitrogen response of corn under variable conditions of drainage-A lysimeter study. Soil Science, 72, 93-100.

[21] Lal, R. and Taylor, G.S. (1969) Drainage and nutrient effects in a field lysimeter study: I. Corn yield and soil conditions. Soil Science Society of America Journal, 33, 937944. doi:10.2136/sssaj1969.03615995003300060039x

[22] Spek, L.Y. (1981) Influence of nitrate and aeration on growth and chemical composition of Zea mays L. Plant and Soil, 63, 115-120. doi:10.1007/BF02374266

[23] Meyer, W.S., Barrs, H.D., Mosier, A.R. and Schaefer, N.L. (1987) Response of maize to three short-term periods of waterlogging at high and low nitrogen levels on undisturbed and repacked soil. Irrigation Science, 8, 257-272. doi:10.1007/BF00257510

[24] Gallagher, R.N., Weldon, G.O. and Boswell, F.C. (1976) A semi-automated procedure for total nitrogen in plant and soil samples. Soil Science Society of America Journal, 40, 887-889. doi:10.2136/sssaj1976.03615995004000060026x

[25] Patrick, W.H., Gambrell, R.P. and Faulkner, S.P. (1996) Redox measurements of soils. pp. 1255-1273. In: Sparks, D.L., et al., Eds., Methods of Soil Analysis. Part 3: Chemical Methods, Soil Science Society of America, Inc. Madison, 1390.

[26] SAS Institute (2000) SAS/STAT user's guide. Release 6.03. SAS Institute, Cary, $494 \mathrm{p}$.

[27] Atkinson, D. (1973) Some general effects of phosphorus deficiency on growth and development. New Phytologist, 72, 101-111. doi:10.1111/j.1469-8137.1973.tb02014.x

[28] Aerts, R., Boot, R.G.A. and van der Aart, P.J.M. (1991) The relation between above- and belowground biomass allocation patterns and competitive ability. Oecologia, 87, 551-559. doi:10.1007/BF00320419

[29] Crawford, R.M. (1993) Plant survival without oxygen. Biologist, 40, 110-114.

[30] Singh, R. and Ghildyal, B.P. (1980) Soil submergence effects on nutrient uptake, growth, and yield of five corn cultivars. Agronomy Journal, 72, 737-741. doi:10.2134/agronj1980.00021962007200050011x

[31] Voesenek, L.A.C.J., Colmer, T.D., Pierik, R., Millenaar, F.F. and Peeters, A.J.M. (2006) How plants cope with complete submergence. New Phytologist, 170, 213-226. 
doi:10.1111/j.1469-8137.2006.01692.x

[32] Crawford, R.M., Studer, C. and Studer, K. (1989) Deprivation indifference as a survival strategy in competition: Advantages and disadvantages of anoxia tolerance in wetland vegetation. Flora, 182, 189-201.

[33] Insausti, P., Chaneton, E.J. and Soriano, A. (1999) Flooding reverted grazing effects on plant community structure in mesocosms of lowland grassland. Oikos, 84, 266-276. doi: $10.2307 / 3546721$

[34] Loreti, J. and Oesterheld, M. (1996) Intraspecific variation in the resistance to flooding and drought in populations of Paspalum dilitatum from different topographic positions. Oecologia, 92, 279-284.

[35] Laan, P., M. Tosserama, M., Blom, C.W.P.M. and Veen, B.W. (1990) Internal oxygen transport in Rumex species and its significance for respiration under hypoxic conditions. Plant and Soil, 122, 39-46. doi:10.1007/BF02851908

[36] Van der Samn, A.J.M., Voesenek, L.A.C.J., Blom, C.W.P.M., Harren F.J.M. and Reuss, J. (1991) The role of ethylene in shoot elongation with respect to survival and seed output of flooded Rumes maritimus L. plants. Functional Ecology, 5, 304-313. doi:10.2307/2389269

[37] Kozlowski, T.T. (1984) Plant responses to flooding. BioScience, 34, 162-167. doi:10.2307/1309751

[38] Luttge, V. and Pitman, M.G. (1976) Transport and energy. Encyclopedia of Plant Physiology: New Series, 2A, 251259.

[39] Hart, R.H., Burton, G.W. and Jackson, J.E. (1965) Seasonal variation in chemical composition and yield of Coastal bermudagrass as affected by nitrogen fertilization schedule. Agronomy Journal, 57, 381-385. doi:10.2134/agronj1965.00021962005700040022x

[40] Mathias, E.L., Bennett, O.L. and Lundberg, P.E. (1973) Effect of rates of nitrogen on yield, nitrogen use, and winter survival of Midland bermudagrass (Cynodon dactylon, L) in Appalachia. Agronomy Journal, 65, 67-68. doi:10.2134/agronj1973.00021962006500010020x

[41] Horn, F.P. and Taliaferro, C.M. (1974) Yield, composition, and IVDMD of four bermudagrass. Journal of Animal Science, 38, 224.

[42] Barth, K.M., McLaren, J.B., Fribourg, H.A. and Carver,
L.A. (1982) Crude protein content of forage consumed by steers grazing nitrogen-fertilized. Bermuda Grass and Orchard Grass-Ladino Clover Pastures, 50.

[43] Chen, H., Qualls, R.G. and Miller, G.C. (2002) Adaptive response of Lepidium latifolium to soil flooding: Biomass allocation, adventitious rooting, arenchyma formation and ethylene production. Environmental and Experimental Botany, 48, 119-128. doi:10.1016/S0098-8472(02)00018-7

[44] Chapin, F.S. (1980) The mineral nutrition of wild plants. Annual Reviews of Ecology and Systematics, 11, 233-260. doi:10.1146/annurev.es.11.110180.001313

[45] Sigua, G.C. and Hudnall, W.H. (1992) Nitrogen and gypsum: Management tools for revegetation and productivity improvement of brackish marsh in southwest Louisiana. Communications in Soil Science and Plant Analysis, 23, 283-299. doi:10.1080/00103629209368588

[46] Aulahk, M.S. and Singh, B. (1997) Nitrogen losses and fertilizer $\mathrm{N}$ use efficiency in irrigated porous soils. $\mathrm{Nu}$ trient Cycling in Agroecosystems, 47, 197-212.

[47] Wiljler, J. and Delwiche, C.C. (1954) Investigations on the denitrifying processes in soil. Plant and Soil, 5, 155169. doi:10.1007/BF01343848

[48] Russel, E.W. (1961) Soil conditions and plant growth. 9th Edition, Longmans, Green, London.

[49] Patrick, W.H. and Wyatt, R. (1964) Soil nitrogen loss as a result of alternate submergence and drying. Soil Science Society of America Journal, 28, 647-653. doi:10.2136/sssaj1964.03615995002800050021x

[50] MacRae, I.C., Ancajas, R.R. and Salandanan, S. (1967) The fate of nitrate nitrogen in some tropical soils following submergence. Soil Science, 105, 327-334. doi:10.1097/00010694-196805000-00007

[51] Tusneem, M.E. and Patrick Jr., W.H. (1971) Nitrogen transformations in waterlogged soil. Louisiana State University Agricultural Experiment Bulletin, 657, 75.

[52] Sigua, G.C., Williams, M.J., Grabowski, J., Chase, C. and Kongchum, M. (2012) Effect of flooding duration and nitrogen fertilization on yield and protein content of three forage species. Agronomy Journal, 104, 791-798. doi:10.2134/agronj2011.0364 